\title{
PENGARUH PENDIDIKAN ETIKA BISNIS DAN RELIGIUSITAS TERHADAP PERSEPSI ETIS MAHASISWA AKUNTANSI
}

\author{
Mirna Wati \& Bambang Sudibyo \\ Universitas Gadjah Mada, Indonesia \\ Email:mirna.wati915@gmail.com
}

\begin{abstract}
Abstrak: Pengaruh Pendidikan Etika Bisnis dan Religiusitas Terhadap Persepsi Etis Mahasiswa Akuntansi. Penelitian ini bertujuan melihat hubungan antara pendidikan etika, gender, religiusitas, dan performa akademik terhadap persepsi etis mahasiswa. Penelitian ini juga ingin membuktikan perbedaan persepsi antara mahasiswa yang sudah atau sedang mengambil mata kuliah etika bisnis dan yang belum, antara mahasiswa laki-laki dan perempuan, serta mahasiswa dengan IPK $\geq 3,3$ dan $<3,3$. Metode analisis data yang digunakan yaitu analisis regresi berganda dan uji beda independent sample t-test. Hasil penelitian menunjukkan bahwa pendidikan etika dan performa akademik tidak berpengaruh signifikan terhadap persepsi etis mahasiswa, berbeda halnya dengan religiusitas dan gender yang memiliki pengaruh yang signifikan. Hasil uji beda menunjukkan perbedaan persepsi etis antara yang sudah atau sedang mengambil mata kuliah etika bisnis dengan yang belum, sama halnya dengan mahasiswa laki-laki dan perempuan.
\end{abstract}

Kata kunci: Pendidikan etika, Religiusitas, Persepsi Etis

\begin{abstract}
The Influence of Business Ethics Education and Religiosity to Ethical Perception of College Students. The objective of this study is to examine the influence of ethics education, gender, religiosity, and academic performance to the ethical perception of undergraduate. The additional examination was done to know the differences perception between students who have accomplished business ethics course and who have not accomplished business ethics course yet, male and female students, and students who have high GPA and low GPA. The analysis data method uses multiple regression and independent sample t-test. The result indicates that ethics education and academic performance have no significant influence on the ethical perception of college students. On the other hand, religiosity and gender have a significant influence on ethical perception. The result of independent sample t-test indicates that significantly difference between student's perceptions who have accomplished business ethics course and who have not accomplished yet, likewise between male and female students.
\end{abstract}

Keyword: Ethics Education, Religiosity, Ethical Perception

\section{PENDAHULUAN}

Etika merupakan suatu bagian yang tidak dapat dipisahkan dari kehidupan sehari-hari seseorang, tidak terkecuali dalam dunia bisnis. Masyarakat di Indonesia pada dasarnya dibangun atas dasar aturan-aturan etika. Bisnis harus beroperasi dalam suatu tatanan sosial yang dalam beberapa metodenya sama etisnya dengan peraturan perundangan, politik, ekonomi, dan sosial yang melingkupinya. Kegiatan akuntansi memiliki hubungan yang sangat erat dengan etika. Hal ini terjadi karena kegiatan akuntansi membutuhkan judgement dari 
seorang akuntan dan dalam realitanya tidak mudah untuk mengambil judgement. Oleh sebab itu, kesadaran etika dibutuhkan oleh seorang akuntan dalam pengambilan keputusan akuntansi.

Etika adalah nilai-nilai tingkah laku atau aturan tingkah laku yang diterima dan digunakan oleh individu atau suatu golongan tertentu. Etika berasal dari bahasa Yunani kuno. Kata Yunani ethos dalam bentuk tunggal mempunyai banyak arti: tempat tinggal yang biasa, padang rumput, kandang; kebiasaan, adat; akhlak, watak; perasaan, sikap, cara berpikir. Dalam bentuk jamak ( $t a$ etha) artinya adalah adat kebiasaan. Arti adat kebiasaan inilah yang menjadi latar belakang terbentuknya istilah etika. Apabila istilah etika dibatasi maka etika merupakan ilmu tentang apa yang bisa dilakukan atau ilmu tentang adat kebiasaan, bisa juga dikatakan bahwa etika berarti ilmu yang menyelidiki tingkah laku moral (Farhan, 2009).

Siagian (1996) menyebutkan bahwa setidaknya ada 4 alasan mengapa mempelajari etika sangat penting: (1) etika memandu manusia dalam memilih berbagai keputusan yang dihadapi dalam kehidupan, (2) etika merupakan pola perilaku yang didasarkan pada kesepakatan nilai-nilai sehingga kehidupan yang harmonis dapat tercapai, (3) dinamika dalam kehidupan manusia menyebabkan perubahan nilai-nilai moral sehingga perlu dilakukan analisa dan ditinjau ulang, (4) Etika mendorong tumbuhnya naluri moralitas dan mengilhami manusia untuk sama-sama mencari, menemukan dan menerapkan nilai-nilai hidup yang hakiki. Dengan begitu, perlu adanya peningkatakan penerapan etika dalam dunia pendidikan, sehingga tindakan calon akuntan dapat terkontrol.

Etika telah menjadi isu penting dan menyedot perhatian baik dalam bidang akademik maupun profesi. Banyak kasus yang muncul berkaitan dengan persoalan etika. Sebagai contoh, skandal yang melibatkan beberapa perusahaan besar seperti Enron, KAP Arthur Anderson, dan Worldcom (Angelidis dan Ibrahim, 2004).

Enron melakukan manipulasi angkaangka pada pengungkapan laporan keuangan periode 1997 hingga 2000 dengan melakukan penggelembungan (mark up) atas pendapatan sebesar US\$ 600 juta dan menyembunyikan utangnya sebesar US\$ 1,2 miliar yang dilakukan oleh manajemen Enron dengan tujuan untuk mendapatkan kepercayaan pemegang saham sehingga harga saham tetap tinggi. Enron dibantu oleh KAP Arthur Anderson dalam memanipulasi laporan keuangannya. Pada tahun 2002, KAP Arthur Anderson dinyatakan bersalah karena melakukan upaya untuk menutupi kecurangan yang dilakukan Enron dengan menghilangkan semua dokumen termasuk email dan berkas-berkas perusahaan yang berhubungan dengan jasa audit yang diberikan kepada Enron (Comunale et al, 2006).

Hal serupa juga terjadi pada Worlcom. Perusahaan telekomunikasi terbesar di dunia itu terbukti bersalah di tahun 2003. Worldcom melakukan kecurangan pada laporan keuangannya. Kecurangan itu dilakukan guna menyembunyikan pendapatan Worldcom yang merosot untuk mempertahankan harga saham. Worldcom mencatat beban interkoneksi dengan perusahaan telekomunikasi lain sebagai 
capital expenditures, sehingga transaksi yang seharusnya dicatat sebagai beban justru dicatat sebagai aset. Hal tersebut mengakibatkan aset perusahaan overvalued (Moberg dan Romar, 2009).

Kasus skandal etika serupa juga banyak terjadi di Indonesia. Salah satunya yaitu perusahaan obat besar di Indonesia yaitu PT Kimia Farma Tbk yang pada tahun 2001 melakukan manipulasi laporan keuangan. Pada audit tanggal 31 Desember 2001, laba bersih yang dilaporkan oleh manajemen sebesar Rp132 miliar dengan menggunakan jasa audit Hans Tuanakotta \& Mustofa (HTM). Akan tetapi, dari hasil pemeriksaan Bapepam terdapat kesalahan penyajian dalam laporan keuangan PT KAEF, adapun dampak kesalahan tersebut mengakibatkan overstated laba pada laba bersih untuk tahun yang berakhir 31 Desember 2001 sebesar Rp 32,7 miliar yang merupakan 2,3\% dari penjualan dan $24,7 \%$ dari laba bersih PT Kimia Farma Tbk (Bapepam, 2002).

Banyaknya skandal etika yang terjadi dalam dunia akuntansi dan bisnis mengindikasikan pentingnya pengajaran etika bisnis kepada mahasiswa fakultas ekonomika dan bisnis (FEB) khususnya akuntansi sebagai calon akuntan dan pemimpin bisnis masa depan. Cohen et al., (1998) berpendapat bahwa peraturan pemerintah tidak dapat sepenuhnya menjamin perilaku etis, sehingga dibutuhkan adanya pendidikan etika bisnis. Maka dari itu, di tahun 1986, anggota dari AICPA (the American institute of Certified public Accountant) setuju untuk mengadakan pendidikan etika bisnis di program akuntansi. AAA (American Accounting Association) mengeluarkan sebuah pengumuman tentang konten dari pendidikan akuntansi dan pentingnya etika bisnis dalam akuntansi. Pengumuman tersebut menjelaskan bahwa pendidikan profesional harus tidak hanya fokus pada kemampuan dan pengetahuan tetapi juga pada prinsip dan komitmen etika dalam profesi akuntansi. Mahasiswa akuntansi dapat dibekali kurikulum yang berkaitan dengan permasalahanpermasalahan etika di dunia profesi agar nantinya mahasiswa akuntansi sebagai calon akuntan lebih mengetahui pertimbagan etis dan pengambilan keputusan yang etis. Mengingat bahwa akuntan memegang peranan penting bagi masyarakat. Informasi yang disediakan oleh akuntan melalui laporan keuangan perusahaan sangat penting dan dibutuhkan oleh pihak manajemen, investor, dan pemangku kepentingan lain dalam mengambil keputusan. Pelanggaran etika bisnis yang dilakukan oleh akuntan dapat merugikan masyarakat dan menimbulkan ketidakpercayaan masyarakat kepada akuntan.

Maraknya skandal etis yang terjadi khususnya pada dunia profesi akuntan dan corporate managemer mencerminkan adanya krisis etis yang melanda dunia etika bisnis dan profesi. Sehingga peneliti merasa bahwa penelitian mengenai persepsi etis terhadap isu etika penting untuk dilakukan. Matlin (1998) mendefinisikan persepsi sebagai suatu proses yang melibatkan pengetahuan-pengetahuan sebelumnya dalam memperoleh, menginterpretasikan kombinasi faktor dunia luar (stimulus visual), dan diri kita sendiri (pengetahuanpengetahuan sebelumnya). Persepsi dipelajari secara luas, dan tidak ada seorang 


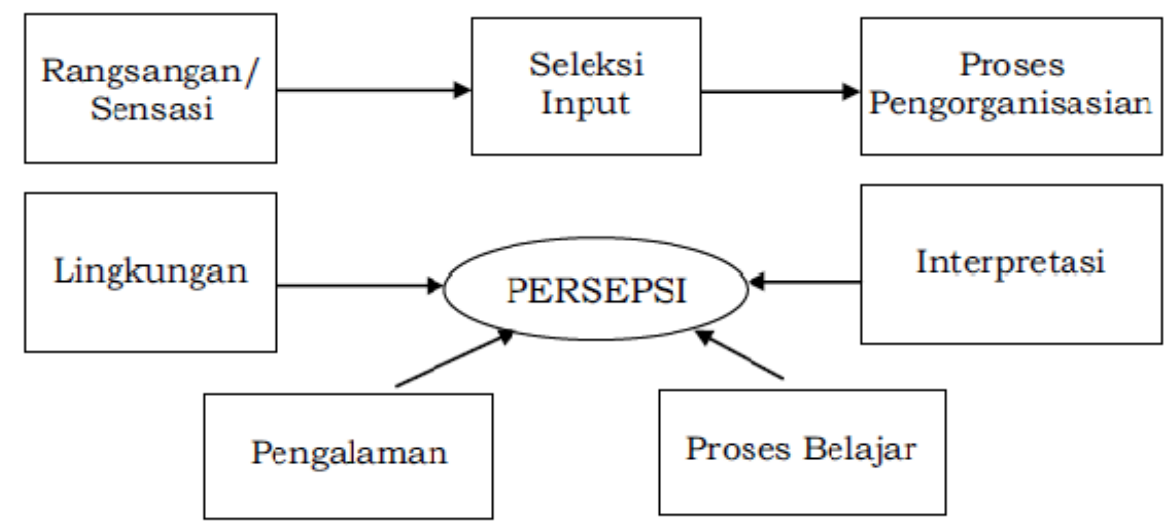

Gambar 1. Skema Pembentukan Persepsi (Damayanthi, 2000)

pun yang punya pengetahuan dan pengalaman yang sama, maka setiap orang yang memiliki filter yang unik dan situasi atau rangsangan yang sama bisa jadi menghasilkan reaksi dan perilaku yang sangat berbeda (Luthans, 2006). Setiap orang memiliki perbedaan dalam menginterpretasikan objek yang mereka terima melalui panca indera. Perbedaan ini terjadi karena dalam diri seseorang terdapat dua faktor yaitu faktor kognitif dan faktor dunia luar atau stimulus visual. Persepsi pada dasarnya menyangkut hubungan manusia dengan lingkungannya, bagaimana ia mengerti dan menginterpretasikan stimulus yang ada di lingkungannya. Setelah individu menginderakan objek di lingkungannya, kemudian ia memproses hasil penginderaannya, sehingga timbullah makna tentang objek tersebut pada dirinya yang dinamakan persepsi (Desmita, 2005). Proses pembentukan persepsi dapat dilihat dari Gambar 1.

Menurut Smith (2009) setiap mahasiswa mempunyai persepsi moral, penilaian dan perilaku yang berbeda-beda, meskipun mereka telah diberikan pendidikan etika dengan porsi yang sama. Pendidikan etika bagi seseorang di era globalisasi ini sangat dibutuhkan, sehingga memberikan pemahaman tentang konsep etika yang lebih jelas. Pendidikan etika penting karena adanya bias keinginan sosial, yaitu kecenderungan seseorang untuk overestimate atau underestimate kemungkinan untuk melakukan tindakan yang disukai atau tidak disukai (Chung dan Monroe, 2003). Fokus pada pendidikan etika juga menjadi salah satu bahan pertimbangan dalam penelitian karena pendidikan etika merupakan salah satu faktor dalam membentuk karakter individu di masa datang.

Banyak pula yang berpendapat bahwa pendidikan etika tidak dapat diajarkan, akan tetapi sejak memperbaharui standar dengan lebih menekankan pada pendidikan etika pada bulan April 2003, lembaga akreditasi terkemuka Advance Collegiate Schools of Business (AACSB) International menyatakan bahwa topik etika harus menjadi bagian dari kurikulum baik sarjana maupun pascasarjana. (Dean et al., 2007).

Fokus pada pendidikan etika juga menjadi salah satu bahan pertimbangan dalam penelitian karena pendidikan etika 
merupakan salah satu faktor dalam membentuk karakter individu di masa datang. Kerr dan Smith (1995) menyelidiki persepsi mahasiswa akuntansi tentang metode partisipasi etika dalam kursus akuntansi. Hasil penelitian mereka menunjukkan siswa percaya bahwa etika adalah subjek utama dalam bisnis dan profesi akuntansi gagal tanpa etika. Menurut Duska (1991) seseorang memerlukan tiga hal untuk berperilaku etis yaitu mengetahui hal baik, menyukai hal baik, dan melakukan hal baik. Seseorang yang telah mendapat pendidikan etika diasumsikan telah mengetahui hal baik, sehingga orang tersebut dapat berperilaku lebih etis dibandingakan seseorang yang belum mengambil pendidikan etika. Berdasarkan uraian tersebut hipotesisi pertama $(\mathrm{H} 1)$ adalah terdapat perbedaan persepsi etis antara mahasiswa yang sudah atau sedang mengambil mata kuliah etika bisnis dan mahasiswa yang belum mengambil mata kuliah etika bisnis.

Permasalahan lain muncul ketika perilaku etis dihadapkan dengan perbedaan gender. Gender merupakan faktor individu yang mempengaruhi perilaku etis. Galbraith dan Stephenson (1993) melaporkan bahwa pria dan wanita pada umumnya, meskipun tidak selalu, menggunakan aturan keputusan yang berbeda ketika membuat penilaian etis dan bahwa ada juga keragaman yang lebih besar dalam aturan keputusan yang digunakan oleh wanita dibandingkan dengan yang digunakan oleh laki-laki. Roxas dan Stoneback (2004) menyatakan bahwa memahami perbedaan respon etika antara laki-laki dan perempuan semakin penting karena akhir-akhir ini jumlah perempuan yang memegang posisi penting dalam dunia bisnis dan lingkungan kerja lainnya naik secara signifikan.

Palmer dan Tamilselvi mengklasifikasikan gender dalam dua stereotype, yaitu sex role stereotype dan managerial stereotype. Pandangan sex role stereotype menyatakan bahwa laki-laki lebih berorientasi pada pekerjaan, objektif, independen, agresif dan lebih bertanggung jawab dalam hal manajerial. Sedangkan wanita dianggap lebih pasif, lembut, berorientasi pada pertimbangan, lebih sensitif dan rendah posisinya pada pertanggungjawaban dalam organisasi. Managerial stereotype menyatakan bahwa pria sebagai orang yang lebih memiliki sikap, perilaku, dan temperamen dibandingkan wanita. Dari pernyataan tersebut timbul keyakinan bahwa wanita lebih memiliki sensitivitas etis dibandingkan pria di dalam situasi berdilema etis (Cohen et al., 1998). Beberapa studi mendukung bahwa laki-laki lebih rentan untuk berperilaku tidak etis dibanding perempuan (Betz et al., 1989; Kidwell et al., 1987; Beltramini et al., 1984). Dari pernyatan tersebut, maka hipotesis kedua $(\mathrm{H} 2)$ yang diajukan adalah terdapat perbedaan persepsi etis antara mahasiswa laki-laki dan perempuan.

Faktor individu lain yang mempengaruhi perilaku etis yaitu religiositas. Isu mengenai peran dari agama dan spiritualitas dalam konteks bisnis mendapat peningkatan perhatian beberapa tahun terakhir. Penelitian sebelumnya mengindikasikan bahwa pelatihan religiusitas dan keyakinan berpotensi untuk mempengaruhi perilaku dengan menyediakan kerangka kerja untuk membantu membedakan antara benar dan salah (Magill, 1992). Woodbine et al., (2009) 
menyatakan bahwa hampir semua agama dan sistem kepercayaan memiliki aturan untuk semua penganutnya agar berperilaku etis dalam semua aspek kehidupan termasuk bisnis. Dukungan lain juga diperoleh dari hasil penelitian Weibe dan Fleck (1980) yang menemukan bahwa seseorang yang menerima agama sebagai fokus utama dari hidup mereka (intrinsik) cenderung untuk memiliki perhatian pada standar moral yang lebih tinggi, disiplin, dan bertanggung jawab dari mereka yang tidak religius. Dukungan lain juga diperoleh dari hasil penelitian Oklesehan dan Hoyt (1996) bahwa orientasi religius berpengaruh pada penalaran moral individu. Dari pernyataan-pernyataan di atas, dapat disimpulkan bahwa semakin seseorang taat dengan ajaran agamanya, maka diduga ia akan semakin etis pula perilaku dan sikapnya. Maka dari itu, hipotesis ketiga (H3) yang diajukan adalah terdapat perbedaan persepsi etis antara mahasiswa yang memiliki tingkat religiusitas tinggi dan mahasiswa yang memiliki religiusitas rendah.

Faktor selanjutnya yang dapat mempengaruhi perilaku etis yaitu intelektual seorang mahasiswa. Dalam penelitian ini lebih menekankan pada performa akademik yang digambarkan dengan indeks prestasi kumulatif. Menurut Pascarella dan Terenzini (2005) pencapaian yang diindikasikan dengan nilai merupakan indikator yang paling mengungkapkan intelektual seorang mahasiswa. Pernyataan ini didukung dengan penemuan yang konsisten dari Trail et al., (2006), mengatakan bahwa indeks prestasi merupakan prediksi terbaik dari keberhasilan akademik. Menurut Kamus Besar Bahasa Indonesia (Tim Penyusun Kamus Pusat Pembinaan dan Pengembangan Bahasa,
1995) indeks prestasi adalah angka yang menunjukkan prestasi seseorang dalam belajar atau bekerja. Putri (2015) menyatakan indeks prestasi adalah nilai ratarata hasil program studi mahasiswa selama satu semester. Sedangkan indeks prestasi kumulatif merupakan rata-rata nilai mahasiswa selama ia menempuh program studi bersangkutan. Penelitian yang dilakukan terhadap mahasiswa berkulit hitam oleh Zang dan Smith (2011) yang menguji tentang hubungan performa akademik dengan etika, menemukan bahwa etika akademik berhubungan erat dengan performa akademik. Bloodgood et al., (2007) juga melakukan penelitian yang menghubungkan antara intelektualitas dengan permasalahan kecurangan pada mahasiswa. Ditemukan bahwa semakin tinggi intelektual seorang mahasiswa, maka akan semakin rendah tingkat keinginan dia untuk melakukan tindakan curang. Berdasarkan uraian tersebut maka hipotesis keempat $(\mathrm{H} 4)$ yang diajukan adalah terdapat perbedaan persepsi etis antara mahasiswa dengan peforma akademik tinggi dan mahasiswa dengan peforma akademik lebih rendah.

Penelitian terdahulu pernah dilakukan oleh Suwardi et al., (2014) dengan judul Student Perception of Business Ethics. Penelitian tersebut membandingkan persepsi antara kelompok mahasiswa berdasarkan tingkat kedewasaan mereka, pendidikan formal etika bisnis, gender, dan latar belakang profesi spesifik. Mahasiswa yang menjadi sampel adalah mahasiswa S-1 Fakultas Ekonomika dan Bisnis dan mahasiswa S-1 Fakultas Farmasi Universitas Gadjah Mada. Hasil dari penelitian tersebut yaitu terdapat perbedaan persepsi etika 
bisnis terutama yang bersangkutan dengan profesi masing-masing. Penemuan yang mencengangkan adalah mahasiswa S1 Akuntansi FEB memiliki kesadaran etika bisnis lebih rendah dibanding mahasiswa farmasi. O'Clock dan Okleshen (1993) juga membandingkan persepsi etika pada mahasiswa bisnis dan mahasiswa teknik. Dari hasil analisa yang menggunakan two-tail $t$ test dapat disimpulkan bahwa jebakan perceptual (perceptual trap), atau disparitas diri (self) versus yang lain ada untuk seluruh sampel. Kecuali dalam hal "whistle blowing," mahasiswa teknik lebih sensitif dibandingkan mahasiswa bisnis, dan kedua kelompok mahasiswa merasakan diri mereka lebih etis dibandingkan dengan kelompok lainnya dalam keyakinan dan tindakannya.

Ludigdo (1998) juga meneliti mengenai persepsi akuntan dan mahasiswa terhadap etika bisnis. Tujuan dari penelitiannya yaitu untuk membandingkan persepsi etika bisnis di antara akuntan pria dan akuntan wanita, serta antara mahasiswa dan mahasiswi akuntansi. Hasil yang diperoleh yaitu akuntan pria maupun akuntan wanita tidak mempunyai persepsi yang berbeda terhadap etika bisnis. Demikian halnya antara mahasiswa dan mahasiswi akuntansi juga tidak mempunyai perbedaan persepsi terhadap etika bisnis.

Berbeda dari penelitian-penelitian yang sebelumnya, variabel yang digunakan sebagai dasar pembanding persepsi etis dalam penelitian ini adalah pendidikan formal etika bisnis, gender, religiusitas, dan performa akademik. Dalam penelitian yang dilakukan oleh Suwardi et al., (2014); O'Clock dan Okleshen (1993); dan Ludigdo (1998) dasar pembanding persepsi yang digunakan tidak menggunakan variabel pendidikan formal etika bisnis, religiositas, dan performa akademik. Variabel-variabel tersebut dipilih sebagai bahan dalam penelitian karena sesuai dengan penjelasan sebelumnya bahwa pendidikan formal etika bisnis, religiositas, dan performa akademik yang dapat mempengaruhi perilaku etis seseorang.

Penelitian ini bertujuan untuk membandingkan persepsi etis mahasiswa terhadap etika bisnis jika memperhatikan pendidikan formal etika bisnis dan profesi, gender, religiusitas, dan peforma akademik. Di samping itu untuk melihat apakah kesadaran terhadap etika bisnis mahasiswa S1 Akuntansi tetap rendah meskipun Fakultas Ekonomika dan Bisnis Universitas Gadjah Mada sudah terakreditasi oleh Advance Collegiate Schools of Business (AACSB) International yang mewajibkan adanya mata kuliah etika bisnis. Maka dari itu, Subjek yang digunakan pada penelitian ini adalah mahasiswa S1 Akuntansi Fakultas Ekonomika dan Bisnis Universitas Gadjah Mada. Hasil penelitian ini juga diharapakan dapat memberikan masukan baik bagi universitas maupun fakultas terutama fakultas ekonomika dan bisnis dalam mempertimbangkan muatan etika dalam kurikulum mata kuliah etika bisnis dan profesi.

\section{METODE}

Populasi dalam penelitian ini adalah mahasiswa S-1 jurusan akuntansi Fakultas Ekonomika dan Bisnis Universitas Gadjah Mada dari angkatan 2012-2015 sebanyak 506 orang. Dari populasi tersebut, penulis mengambil sejumlah mahasiswa untuk dijadikan sampel penelitian. 
Jurnal Economia, Volume 12, Nomor 2, Oktober 2016

Tabel 1 Karakterisitk Demografi Responden

\begin{tabular}{llll}
\hline Karakteristik & Kategori & Jumlah & Persentase \\
\hline \multirow{2}{*}{ Gender } & Laki-Laki & 53 & $35 \%$ \\
& Perempuan & 97 & $65 \%$ \\
\hline \multirow{2}{*}{ IPK } & $\geq 3,3$ & 108 & $72 \%$ \\
& $<3,3$ & 42 & $28 \%$ \\
\hline \multirow{3}{*}{ Agama } & Islam & 130 & $87 \%$ \\
& Katholik & 5 & $3 \%$ \\
& Kristen & 9 & $6 \%$ \\
& Hindu & 2 & $1 \%$ \\
& Budha & 1 & $1 \%$ \\
\multirow{2}{*}{ Pendidikan Etika } & Lain-Lain & 3 & $2 \%$ \\
& Sudah atau Sedang & 65 & $43 \%$ \\
& Belum & 85 & $57 \%$ \\
\hline
\end{tabular}

Pengambilan sampel menggunakan metode purposive sampling. Dengan metode purposive sampling diharapkan kriteria sampel yang diperoleh benar-benar sesuai dengan tujuan penelitian. Dengan metode ini, peneliti mengambil sampel yang hanya memenuhi kriteria-kriteria tertentu dan membuang item-item yang sampel yang tidak memenuhi kriteria (Hartono, 2013). Kriteria sampel dalam penelitian ini yaitu mahasiswa yang sudah atau sedang mengambil mata kuliah Etika Bisnis dan mahasiswa yang belum mengambil mata kuliah Etika Bisnis dan mahasiswa dengan IPK $\geq 3,3$ atau $<3,3$ sehingga dapat terlihat perbedaan persepsi etis antara mahasiswa yang sudah atau sedang mengambil mata kuliah Etika Bisnis dan mahasiswa yang belum mengambil mata kuliah Etika Bisnis dan mahasiswa dengan IPK $\geq 3,3$ atau $<3,3$.

Jenis metode purposive sampling yang digunakan dalam penelitian ini yaitu metode quota sampling. Dalam quota sampling didasarkan pada karakteristik populasi dalam jumlah yang telah ditetapkan (kuota) dengan tujuan meningkatkan derajat keterwakilan masing-masing kelompok populasi (Suliyanto, 2006). Metode ini digunakan untuk memastikan bahwa berbagai subgrup dalam populasi telah terwakili dengan berbagai karakteristik sampel sampai batas tertentu seperti yang dikehendaki oleh peneliti. Dalam quota sampling, peneliti menentukan target kuota yang dikehendaki (Kuncoro, 2003). Menurut Cooper dan Schindler (2006) logika pengambilan sampel kuota adalah bahwa karakteristik relevan tertentu menggambarkan dimensi populasi. Jika sebuah sampel mempunyai distribusi yang sama pada karakteristik ini, maka hal tersebut memungkinkan untuk menjadi perwakilan dari populasi berdasarkan variabel lain. Dari penjelasan tersebut, maka penulis menetaplan kuota sampel sebanyak 150 responden (27\% dari populasi). Menurut Roscoe (1975) dalam Sekaran (2006) ukuran sampel lebih dari 30 dan kurang dari 500 adalah tepat untuk kebanyakan penelitian.

Dari populasi yang ada terdapat 35\% mahasiswa dan 65\% mahasiswi yang masih aktif dari angkatan 2012-2015 di Fakultas 
Ekonomika dan Bisnis Universitas Gadjah Mada. Berdasarkan komposisi tersebut, agar setiap kelompok terwakili kuota yang ditetapkan untuk mahasiswa yaitu 53 orang, sedangkan untuk mahasiswi sebanyak 97 orang. Persentase untuk kriteria mahasiswa/i yang belum dan mahasiswa yang sudah atau sedang mengambil mata kuliah etika bisnis yaitu $57 \%$ dan 43\%, sehingga komposisi kuota yang ditetapkan yaitu 85 mahasiswa/i yang belum mengambil mata kuliah etika bisnis dan 65 mahasiswa/i yang sedang atau sudah mengambil mata kuliah etika bisnis. Kriteria ketiga yaitu Indeks Prestasi Kumulatif (IPK) mahasiswa. Persentase untuk IPK $\geq 3,3$ sebesar $72 \%$ sedangkan IPK $<3,3$ sebesar $28 \%$, berdasarkan komposisi tersebut kuota yang ditetapkan untuk IPK $\geq 3,3$ sebesar 108 orang dan kuota untuk IPK $<3,3$ sebesar 42 orang. Karakteristik demografi responden dapat dilihat pada Tabel 1.

Responden dibagi menjadi dua kelompok, yaitu mahasiswa yang sudah atau sedang mengambil mata kuliah etika bisnis dan mahasiswa yang belum mengambil mata kuliah etika bisnis. Dengan begitu, dapat terlihat perbandingan kemampuan etis mahasiswa yang sudah menerima materi pendidikan etika bisnis dan mahasiswa yang belum menerima materi pendidikan etika bisnis.

Jenis data yang digunakan dalam penelitian ini adalah data primer yang diambil secara langsung dari mahasiswa S1 jurusan akuntansi Fakultas Ekonomika dan bisnis Universitas Gadjah Mada. Data dikumpulkan menggunakan instrumen kuesioner yang didistribusikan baik secara online melalui type form maupun secara langsung kepada responden. Kuesioner penelitian ini dibagi menjadi dua bagian. Bagian pertama untuk mengukur persepsi mahasiswa mengenai etika bisnis dan bagian kedua untuk mengukur tingkat religiusitas mahasiswa.

Persepsi etis mahasiswa diukur dengan memberikan 17 pernyataan bermuatan etika secara umum. Pernyataan tersebut dinilai dengan skala Likert dimulai dari skala 1 (Sangat Tidak Setuju), 2 (Tidak Setuju), 3 (Netral), 4 (Setuju) hingga skala 5 (Sangat Setuju). Kuesioner mengenai religiusitas lebih mengarah pada religiusitas secara intrinsik. Responden diminta untuk memberikan rating terhadap delapan pernyataan tersebut dengan 7 skala Likert mulai dari 1 (Sangat Tidak Setuju) hingga 7 (Sangat Setuju).

Variabel dependen dalam penelitian ini adalah persepsi etis sedangkan variabel independennya yaitu pendidikan formal etika bisnis dan profesi, dan religiositas. Variabel kontrol dalam penelitian ini adalah gender dan performa akademik.

Penelitian ini menggunakan metode analisis regresi linear berganda yang diolah menggunakan Software SPSS 22 untuk mengetahui pengaruh variabel independen terhadap variabel dependen. Adapun persamaan regresi linear berganda yang digunakan dalam penelitian ini adalah:

$P e=a+b 1 X 1+b 2 X 2+b 3 X 3+b 4 X 4+e$

Keterangan:

$\mathrm{Pe}=$ Persepsi etika Mahasiswa

$\mathrm{a}=$ Konstanta

$\mathrm{b}=$ Koefisien regresi

X1= Pendidikan Etika

$\mathrm{X} 2=$ Religiusitas

$\mathrm{X} 3=$ Jenis Kelamin

$\mathrm{X} 4=$ Performa Akademik

$\mathrm{e}=$ error 
Uji validitas digunakan untuk mengukur valid atau tidaknya suatu kuesioner. Validitas juga menunjukkan seberapa nyata suatu pengujian mengukur apa yang seharusnya diukur (Hartono, 2014). Uji validitas instrumen penelitian dilakukan dengan membandingkan antara nilai korelasi ( $r$ ) hitung dengan korelasi ( $r$ ) tabel. Jika nilai korelasi $(r)$ hitung $>$ dari nilai korelasi $(r)$ tabel, maka instrumen yang digunakan valid. Uji reliabilitas dilakukan menggunakan teknik Cronbach alpha. Menurut Hartono (2014) reliabilitas menunjukkan akurasi dan ketepatan dari pengukurnya. Kuesioner dikatakan reliabel apabila Cronbach alpha > 0,6 (Hair et al., 2010).

Uji asumsi klasik yang digunakan dalam penelitian ini yaitu pertama, uji normalitas yang menggunakan uji Kolmogorov-Smirnov (K-S) yang membandingkan nilai probabilitas dengan nilai signifikansinya. Distribusi dikatakan normal jika probabilitas dalam uji K-S berada di atas 0,05. Kedua, uji multikolinearitas. Pengujian ini bertujuan untuk menguji apakah terdapat korelasi antar variabel independen dalam model regresi. Model regresi yang baik adalah yang tidak terjadi multikolinearitas. Uji multikolinearitas dalam penelitian ini dilakukan dengan menghitung nilai tolerance dan nilai variance inflation factor (VIF). Nilai tolerance menggambarkan tingkat variabilitas variabel independen yang tidak dijelaskan variabel independen lainnya. Jika VIF $<10$ dan nilai tolerance $>0,1$ maka model dapat dikatakan terbebas dari multikolinearitas dan dapat digunakan dalam penelitian (Ghozali, 2011). Ketiga yaitu uji heteroskedastisitas. Model regresi yang baik adalah homoskedastistisitas atau tidak terjadi heteroskedastisitas. Dalam penelitian ini, uji heteroskedastisitas dilakukan dengan uji Glejser. Jika probabilitas signifikan antara variabel independen dengan absolut residual lebih dari 0,05 maka tidak terjadi masalah heteroskedastisitas.

Dalam penelitian ini dilakukan uji hipotesis yang meliputi: a) Uji F Kelayakan Model. Uji F dilakukan untuk mengetahui apakah variabel independen mempunyai pengaruh secara simultan terhadap variabel dependen. Jika $\mathrm{F}$ hitung $>\mathrm{F}$ tabel dan nilai probabilitas $<0,05$, maka seluruh variabel independen secara simultan mempengaruhi variabel dependen dan model regresi berganda layak digunakan; b) Uji Koefisien determinasi $\left(R^{2}\right)$ pada intinya mengukur kemampuan model dalam menerangkan variasi variabel dependen. Nilai koefisisen determinasi adalah antara 0 dan 1 . Jika nilai $R^{2}$ semakin mendekati 1 , maka dapat dikatakan bahwa variabel-variabel independen telah menyediakan informasi yang menjelaskan variabel dependen (Ghozali, 2011); c) Uji t dilakukan untuk mengetahui pengaruh setiap variabel independen secara individual terhadap variabel dependen. Jika nilai probabilitas signifikan lebih kecil dari 0,05 dan t hitung $>\mathrm{t}$ tabel maka hipotesis didukung, sedangkan jika t hitung < t tabel dan nilai probabilitas $>$ 0,05 maka hipotesis ditolak.

Uji beda independent sample t-test juga dilakukan untuk mengetahui apakah sampel yang saling tidak berhubungan memiliki ratarata yang berbeda. Di dalam penelitian ini dua sampel yang tidak saling berhubungan yaitu mahasiswa/i jurusan Akuntansi Fakultas Ekonomika dan Bisnis Universitas Gadjah Mada yang sudah atau sedang 


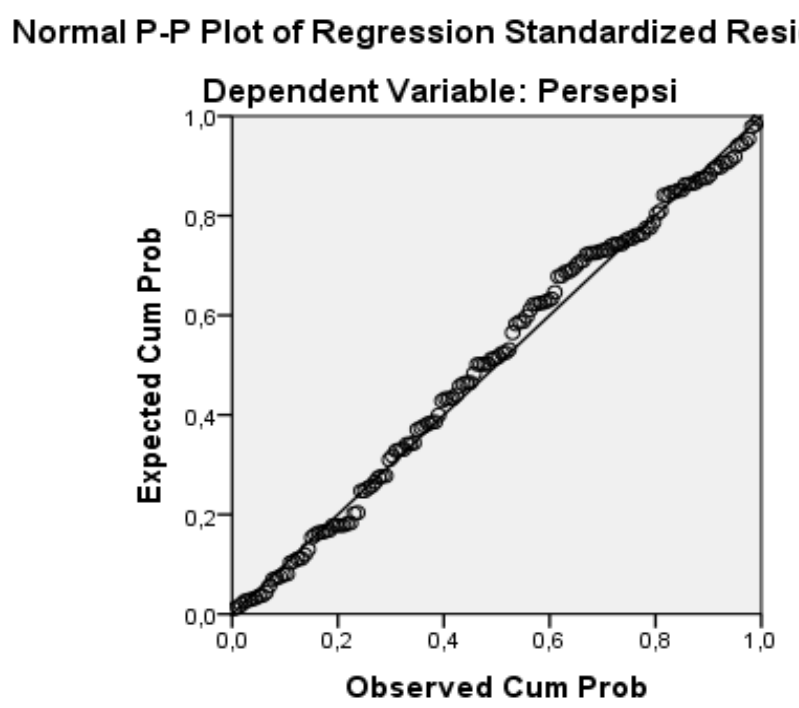

Gambar 2. P-Plot Normalitas

mengambil mata kuliah etika bisnis dan yang belum mengambil mata kuliah etika bisnis, mahasiswa laki-laki dan perempuan, serta mahasiswa/i dengan IPK tinggi dan IPK rendah. Uji beda independent sample t-test ini dilakukan dengan cara membandingkan perbedaan rata-rata dari dua sampel dengan standar eror dari perbedaan rata-rata dua sampel tersebut. Ada dua tahap untuk melakukan uji beda independent sample ttest. Tahap pertama, melakukan Levene's test untuk melihat varians dua sampel bersifat sama ataukah berbeda. Hasil dari Levene's test ini akan menentukan asumsi yang akan digunakan dalam analisis uji beda t-test. Tahap yang kedua uji beda t-test yaitu dengan melihat probabilitasnya. Apabila probabilitas kurang dari 0,05 maka ada perbedaan yang signifikan antara dua sampel (Ghozali, 2011).

\section{HASIL DAN PEMBAHASAN}

Hasil uji validitas instrumen persepsi etis dan religiusitas menunjukkan nilai korelasi ( $r$ ) hitung dari semua item pernyataan lebih dari nilai korelasi $(r)$ tabel. Dalam penelitian ini nilai korelasi ( $r$ ) tabel yaitu 0,1603. Dapat disimpulkan bahwa instrumen variabel persepsi etis dan religiusitas adalah valid. Hasil uji reliabilitas instrumen persepsi etis dan religiusitas menunjukkan nilai Cronbach's Alpha di atas 0,6 dengan nilai masing-masing 0,808 dan 0.943. Hal ini menunjukkan bahwa instrumen untuk tiap variabel reliabel.

Dari hasil uji normalitas diperoleh nilai Kolmogorov-Smirnov Z sebesar 0,071 lebih kecil dari z tabel 1,96. Dengan begitu data residual terdistribusi secara normal. Normalitas juga dapat dilihat pada gambar PPlot Normalitas (Gambar 2). Gambar tersebut memperlihatkan titik-titik data menyebar di sekitar garis liner yang menunjukkan bahwa data terdistribusi secara normal.

Uji multikolinearitas menunjukkan nilai toleransi yang dimiliki variabel independen berada di atas 0,1 dan nilai VIF berkisar antara 1,026-1,206. Hal ini menunjukkan bahwa tidak terjadi multikolinearitas dalam model. 
Jurnal Economia, Volume 12, Nomor 2, Oktober 2016

Tabel 2. Hasil Uji Heteroskedastisitas

\begin{tabular}{lccl}
\hline Variabel & $\mathrm{t}$ & Sig. & Keterangan \\
\hline Gender & $-1,923$ & 0,057 & Non Heteroskedastisitas \\
IPK & $-1,596$ & 0,113 & Non Heteroskedastisitas \\
Pendidikan Etika & 0,400 & 0,690 & Non Heteroskedastisitas \\
Religiusitas & $-1,230$ & 0,221 & Non Heteroskedastisitas \\
\hline
\end{tabular}

Hasil pengujian heteroskedastisitas pada tabel 2 menunjukkan tingkat signifikansi dari seluruh variabel independen dalam model regresi lebih dari 0,05. Angka tersebut menunjukkan bahwa variabel independen yang digunakan dalam model regresi dalam penelitian ini bebas dari masalah heteroskedastisitas.

Setelah model regresi memenuhi uji asumsi klasik, maka kemudian dapat dilakukan uji hipotesis. Hasil uji hipotesis memperlihatkan hasil uji $F$ yang menunjukkan nilai $F$ hitung 5,447 dengan nilai $F$ signifikan pada $\alpha$ sebesar 0,000 jauh lebih kecil dari 0,05. Maka dari itu variabel independen religiusitas, peforma akademik, pendidikan etika, dan gender layak digunakan untuk menguji pengaruh variabel independen terhadap persepsi etis mahasiswa. Setelah dilakukan uji koefisien determinasi (Adjusted $R^{2}$ ) diperoleh angka sebesar 0,107. Hasil tersebut menunjukkan

Tabel 3. Hasil Uji Regresi Berganda

\begin{tabular}{|c|c|c|c|c|c|}
\hline \multirow{3}{*}{ Variabel } & \multirow{2}{*}{\multicolumn{2}{|c|}{$\begin{array}{l}\text { Unstandardized } \\
\text { Coefficients }\end{array}$}} & \multirow{3}{*}{$\begin{array}{l}\text { Standardized } \\
\text { Coefficients } \\
\text { Beta }\end{array}$} & \multirow{3}{*}{$\mathrm{t}$} & \multirow{3}{*}{ Sig. } \\
\hline & & & & & \\
\hline & B & Std. Error & & & \\
\hline (Constant) & 27,742 & 1,878 & & 14,773 & ,000 \\
\hline Gender & 2,270 & 1,135 & 170, & 2,000 & ,047 \\
\hline IPK &,- 786 & 1,127 &,- 056 &,- 697 & ,487 \\
\hline Pendidikan Etika &,- 208 & 1,064 &,- 016 &,- 195 & ,845 \\
\hline Religiusitas & 222 & ,059 & 297 & 3,782 & ,000 \\
\hline
\end{tabular}

bahwa persepsi etis dapat dipengaruhi oleh sudah atau belum responden mengambil mata kulaih etika bisnis, gender, performa akademik, dan religiusitas sebesar 10,7\% sedangkan $89,3 \%$ sisanya dijelaskan oleh variabel lain di luar variabel yang digunakan dalam penelitian ini.

Berdasarkan hasil uji regresi yang ditunjukkan pada tabel 3, maka diperoleh persamaan regresi sebagai berikut:

Persepsi etis $=27,742+2,270$ Gender $-0,786$ IPK - 0,208 Pendidikan Etika + 0,222 Religiusitas + e

Hasil konstanta bernilai positif sebesar 27,742 menunjukkan bahwa persepsi etis mahasiswa/i akuntansi tetap mengalami peningkatan tanpa dipengaruhi oleh variabel pendidikan etika, gender, indeks prestasi akademik (IPK), dan religiusitas jika kedua variabel dianggap konstan atau tidak mengalami perubahan. 
Koefisien regresi $(\beta)$ dari variabel gender sebesar 2,270 dengan nilai t hitung 2,0 dan signifikan pada angka 0,047. Hasil ini dinilai signifikan karena nilai signifikansinya kurang dari 0,05. Jadi, variabel gender berpengaruh secara signifikan terhadap persepsi etis mahasiswa. Sama halnya, variabel religiusitas memiliki tingkat signifikansi kurang dari 0,05 yaitu 0,000 dengan koefisien yang bernilai positif yaitu sebesar 0,222 , sehingga variabel religiusitas memiliki pengaruh yang signifikan terhadap persepsi etis seseorang. Tabel 3 juga menunjukkan bahwa variabel indeks prestasi kumulatif (IPK) tidak memiliki pengaruh yang signifikan terhadap persepsi. Nilai t hitung untuk variabel IPK sebesar 0,697 dan tingkat signifikansi 0,487 atau lebih dari 0,05. Hasil tersebut berarti bahwa IPK secara keseluruhan baik mahasiswa dengan IPK $\geq 3,3$ maupun $<3,3$ tidak berpengaruh secara signifikan terhadap persepsi etis mahasiswa. Variabel pendidikan etika juga memiliki tingkat signifikansi lebih dari 0,05 yaitu sebesar 0,845 dengan $t$ hitung sebesar 0,195. Hasil ini menunjukkan bahwa variabel pendidikan etika bisnis tidak memiliki pengaruh yang signifikan terhadap persepsi etis mahasiwa/i akuntansi.

Uji selanjutnya yang dilakukan yaitu Uji beda Independent Sample T-test. Uji ini dilakukan untuk mengetahui perbedaan ratarata dari dua sampel yang berbeda. Seperti yang dijelaskan sebelumnya, dua sampel yang tidak saling berhubungan dalam penelitian yaitu mahasiswa/i jurusan Akuntansi Fakultas Ekonomika dan Bisnis Universitas Gadjah Mada yang sudah atau sedang mengambil mata kuliah etika bisnis dan yang belum mengambil mata kuliah etika bisnis, mahasiswa laki-laki dan perempuan, serta mahasiswa/i dengan IPK tinggi dan IPK rendah.

Pertama, hasil Uji beda Independent Sample T-test variabel pendidikan etika menunjukkan bahwa Rata-rata nilai untuk mahasiswa/i yang sudah mengambil mata kuliah etika bisnis memiliki nilai yang lebih rendah dibanding mahasiswa/i yang belum mengambil mata kuliah etika bisnis. Rerata nilai untuk mahasiswa/i yang sudah atau sedang mengambil mata kuliah bisnis sebesar 30,6769 berbanding 33,6471 untuk mahasiswa/i yang belum. Namun rata-rata nilai yang lebih kecil mengindikasikan bahwa mahasiswa/i yang sudah atau sedang mengambil kuliah etika bisnis lebih memiliki persepsi etis dibanding mahasiswa/i yang belum dengan rerata nilai yang lebih tinggi. Hal ini disebabkan dari pernyataan untuk variabel persepsi berarah negatif. Dari hasil Levene's Test di atas, $\mathrm{F}$ hitung diperoleh 2,987 dengan tingkat signifikansi sebesar 0,086 lebih besar dari 0,05. Karena tingkat signifikansi lebih besar dari 0,05 maka digunakan asumsi varians sama. $T$ hitung pada asumsi varians sama sebesar 2,912 dengan probabilitas kurang dari 0,05 yaitu sebesar 0,004. Dapat ditarik kesimpulan

Tabel 4. Hasil Uji Independent Sample T-test Pendidikan Etika

\begin{tabular}{llcccc}
\hline & Pendidikan etika & Mean & Std. Deviation & $\mathrm{t}$ & Sig. \\
\hline Persepsi & Belum & 33,6471 & 5,85480 & 2,912 &, 004 \\
& Sudah & 30,6769 & 6,60281 & & \\
\hline
\end{tabular}


Jurnal Economia, Volume 12, Nomor 2, Oktober 2016

Tabel 5. Hasil Uji Independent Sample T-test Gender

\begin{tabular}{cccccc}
\hline & Gender & Mean & Std. Deviation & $t$ & Sig. \\
\hline Persepsi & Perempuan & 31,5155 & 6,80856 & $-2,430$ &, 016 \\
& Laki-laki & 33,9057 & 5,09247 & & \\
\hline
\end{tabular}

bahwa terdapat perbedaan persepsi etis yang signifikan antara mahasiswa/i yang sudah atau sedang mengambil mata kuliah etika bisnis dan mahasiswa yang belum. Penemuan ini sejalan dengan penelitian yang dilakukan oleh Duska (1991). Menurutnya seseorang memerlukan tiga hal untuk berperilaku etis yaitu mengetahui hal baik, menyukai hal baik, dan melakukan hal baik. Seseorang yang telah mendapat pendidikan etika diasumsikan telah mengetahui hal baik, sehingga orang tersebut dapat berperilaku lebih etis dibandingakan seseorang yang belum mengambil pendidikan etika. Dengan begitu, H1 diterima, terdapat perbedaan persepsi antara mahasiswa/i yang sudah atau sedang mengambil mata kuliah etika bisnis dan mahasiswa/i yang belum mengambil mata kuliah etika bisnis.

Kedua, dilihat dari hasil uji independent $t$ test pada tabel 5 terdapat perbedaan yang signifikan antara persepsi etis mahasiswa perempuan dan mahasiswa laki-laki. Dilihat dari rerata nilainya, mahasiswa perempuan memiliki rata-rata nilai lebih kecil yaitu 31,5155 dibanding 33,9057 untuk rata-rata nilai mahasiswa laki-laki. Hasil $F$ hitung Levene's Test yaitu sebesar 8,123 dengan probabilitas 0,005 atau lebih kecil dari 0,05 maka digunakan asumsi variasi tidak sama. Hasil thitung pada asumsi varians tidak sama yaitu sebesar 2,430 dengan probabilitas 0,016 kurang dari 0,05. Dari hasil tersebut dapat disimpulkan bahwa terdapat perbedaan persepsi etis yang signifikan antara mahasiswa perempuan dan laki-laki. Hasil tersebut didukung pula oleh temuan studi dari Betz et al., 1989; Kidwell et al., 1987; Beltramini et al., 1984 bahwa laki-laki lebih rentan untuk berperilaku tidak etis dibanding perempuan. Dari hasil tersebut, maka $\mathrm{H}_{2}$ diterima yaitu terdapat perbedaan persepsi etis antara mahasiswa laki-laki dan mahasiswa perempuan.

Ketiga, tabel 6 memperlihatkan bahwa mahasiswa/i dengan IPK $\geq 3,3$ memiliki ratarata skor sebesar 32,0648 dibanding mahasiswa/i dengan IPK <3,3 dengan rerata skor sebesar 33,1190. Jika dilihat dari Levene's Test, F hitung yang dihasilkan sebesar 0,011 dengan tingkat signifikansi 0,917 atau lebih besar dari 0,05. Sehingga yang digunakan adalah asumsi varians sama. Hasil t hitung pada asumsi varians sama sebesar 0,913 dengan nilai signifikansinya 0,362 lebih besar dari tingkat signifikansi 0,05 .

Tabel 6. Hasil Uji Independent Sample T-test Performa Akademik

\begin{tabular}{lccccc}
\hline & IPK & Mean & Std. Deviation & $t$ & Sig. \\
\hline Persepsi & $<3,3$ & 33,1190 & 6,77586 & 0,913 & 0,362 \\
& $\geq 3,3$ & 32,0648 & 6,17392 & & \\
\hline
\end{tabular}


Dari hasil yang diperoleh, kesimpulan yang dapat diambil adalah tidak terdapat perbedaan yang signifikan antara persepsi etis mahasiswa/i dengan performa akademik tinggi dengan mahasiswa/i dengan performa akademik yang rendah. Penemuan ini tidak sejalan dengan hasil penelitian yang pernah dilakukan oleh Zang dan Smith (2011) yang menguji tentang hubungan performa akademik dengan etika. Mereka menemukan bahwa etika akademik berhubungan erat dengan performa akademik. Hasil dalam penelitian ini juga berbeda dari hasil yang ditemukan oleh Bloodgood et al., (2007) bahwa semakin tinggi intelektual seorang mahasiswa, maka akan semakin rendah tingkat keinginan dia untuk melakukan tindakan curang.

Hubungan performa akademik dan persepsi etis mahasiswa/i yang tidak signifkan disebabkan performa akademik yang digambarkan dengan IPK dalam penelitian ini tidak menjadi jaminan bahwa mahasiswa/i dengan IPK tinggi $(\geq 3,3)$ memiliki persepsi yang lebih etis dibanding mahasiswa/i dengan IPK rendah $(<3,3)$. Bisa saja mahasiswa dengan IPK tinggi malah memiliki persepsi yang kurang etis dibanding dengan mahasiswa/i dengan IPK rendah. Sebagai contoh, seperti kasus Enron dan Worldcom yang dijelaskan sebelumnya. Orang-orang yang terlibat dalam skandal adalah orang-orang dengan pendidikan yang lebih tinggi dibanding pekerja biasa. Dari hasil yang ada maka H4 ditolak, tidak terdapat perbedaan persepsi etis antara mahasiswa dengan performa akademik tinggi dan mahasiswa/i dengan performa akademik rendah.

\section{SIMPULAN}

Berdasarkan hasil penelitian yang diperoleh maka dapat ditarik kesimpulan bahwa terdapat perbedaan persepsi etis yang signifikan antara mahasiswa/i yang sudah atau sedang mengambil mata kuliah etika bisnis dengan mahasiswa/i yang belum dan antara mahasiswa laki-laki dan mahasiswa perempuan. Hal ini dibuktikan dengan hasil Levene's Test dengan probabilitas masingmasing sebesar 0,004 dan 0,016 kurang dari 0,05 dan terdapat perbedaan rata-rata nilai dari hasil uji beda independent $t$-test antara mahasiswa/i yang sudah atau sedang mengambil mata kuliah etika bisnis dengan mahasiswa/i yang belum dan antara mahasiswa perempuan dan laki-laki.

Terdapat perbedaan persepsi etis antara mahasiswa/i yang memiliki tingkat religiusitas tinggi dengan mahasiswa/i yang memiliki tingkat religiusitas rendah. Ditunjukkan dari nilai signifikansi sebesar $0,000(p<0,05)$ dengan standardized beta 0,222 . Berbeda dari hasil yang lainnya, tidak terdapat perbedaan persepsi etis antara mahasiswa/i dengan performa akademik tinggi dan mahasiswa/i dengan performa akademik rendah. Hal ini dibuktikan dengan hasil dari uji beda independent t-test dan Levene's Test yang menunjukkan nilai signifikansi 0,917 atau lebih besar dari 0,05. Ketidaksignifikanan ini menunjukkan bahwa performa akademik tinggi tidak menjamin seseorang memiliki persepsi etis dibanding dengan performa akademik yang rendah. Bisa jadi, mahasiswa/i dengan IPK tinggi memiliki persepsi yang kurang etis dibanding mahasiswa/i dengan IPK rendah. Hal ini dapat dilihat di lingkungan bisnis sekarang ini yang menunjukkan banyak orang dengan IPK 
tinggi tapi berperilaku tidak etis, seperti korupsi dan kolusi.

Variabel pembanding persepsi etis dalam penelitian ini yaitu pendidikan etika, gender, religiositas, dan performa akademik. Kontribusi dari variabel-variabel tersebut hanya sebesar $10,7 \%$ dan $89,3 \%$ sisanya dipengaruhi oleh faktor lain. Bagi peneliti selanjutnya, jika akan ditelusuri lebih dalam maka akan ada variabel lain yang mempengaruhi persepsi etis dan dapat memperluas jumlah sampel yang akan diteliti.

Dari hasil penelitian memperlihatkan terdapat perbedaan persepsi etis antara mahasiswa/i yang sudah atau sedang dan yang belum mengambil mata kuliah etika bisnis, sehingga pendidikan berkarakter dibutuhkan. Pihak universitas dan fakultas sebaiknya memberikan perhatian yang lebih pada muatan etika dalam mata kuliah etika bisnis dan diintegrasikan ke dalam kurikulum-kurikulum. Sudibyo (1995) menjelaskan bahwa dunia pendidikan akuntansi mempunyai pengaruh yang besar terhadap perilaku etis auditor. Hal ini menunjukkan bahwa sikap dan perilaku etis akuntan (auditor) dapat terbentuk melalui proses pendidikan yang berlangsung di dalam institusi pendidikan yang memiliki program studi akuntansi. Maka dari itu, pendidikan karakter sangat dibutuhkan bagi calon akuntan masa depan sebagai bekal untuk menghadapi dilema etika di dunia profesi nantinya.

Pendidikan agama juga tidak kalah penting bagi mahasiswa sehingga dibutuhkan pertimbangan yang baik dalam menentukan muatan materi pada pendidikan agama di perguruan tinggi, seperti mencakup aspek-aspek kontemporer yang sedang marak di masyarakat. Sebaiknya kurikulum yang ada dikembangkan atau diperbaharui mengikuti perkembangan yang ada di masyarakat agar kurikulum tidak hanya terbatas pada aspek normatif saja. Dapat pula melakukan link and match mata kuliah agama dengan permasalahan sesuai dengan jurusan yang diambil mahasiswa, sehingga pendidikan agama tidak sematamata hanya terkonsentrasi pada permasalahan teoritis yang bersifat kognitif tetapi juga harus lebih realistis dan bukan mengulang materi dari tingkat sebelumnya. Sebab dari hasil penelitian ditemukan religiusitas berpengaruh positif terhadap persepsi etis mahasiswa. Secara normatif agama menciptakan sistem makna untuk mengarahkan perilaku kesalehan dalam kehidupan manusia. Pendidikan agama harus mampu memenuhi tujuan agama untuk memberikan kontribusi terhadap terwujudnya kehidupan religiositas. Diperlukan pemahaman konsep keberagamaan secara utuh, tidak hanya cukup pada tataran ritual saja (Fauzan, 2013). Dengan begitu, diharapkan universitas dan fakultas tidak hanya menghasilkan lulusan orang-orang pintar secara intelektual dengan IPK yang tinggi tetapi juga lulusan yang berkarakter dengan akhlak yang baik pula. Mengingat banyaknya skandal etika di dunia profesi akuntan sekarang ini.

\section{DAFTAR PUSTAKA}

Angelidis, J., \& Ibrahim, N. (2004). An Exploratory Study of The Impact of Degree Religiousness Upon an Individual's Corporate Social 
Responsiveness Orientation. Journal of Business Ethics, 51(2), 119

Bapepam. (2002). Siaran Pers Badan Pengawas Pasar Modal. Diakses dari http://www.bapepam. go.id/old/old/news/Des2002/PR 2712 2002.PDF. Pada tanggal 30 Novemver 2016.

Beltramini, R. F. (1991). Concerns of College Students Regarding Business Ethics: A Replication. Journal of Business Ethics, 10(10), 733.

Betz, M., O'Connell, L., \& Shepard, J. M. (1989). Gender Differences In Proclivity For Unethical Behavior. Journal of Business Ethics, 8 (5), 321.

Bloodgood, J. M., Turnley, W. H., \& Mudrack, P. (2007). The Influence of Ethics Instruction Religiosity, and Intelligence on Cheating Behavior. Journal of Business Ethics, 82, 557-571. doi:10.1007/s10551007-9576-0

Chung, J. a. (2003). Exploring Social Desirability Bias. Journal of Business Ethics, 44, 291-302. doi::10.1023/A:1023648703356

Cohen, J. P. (1998). The effect of gender and academic discipline diversity on the ethical evaluations, ethical intentions and ethical orientation of potential public accounting recruits. Accounting Horizons, 12, 250-270.

Comunale, C., Thomas, S dan Gara, S. (2006). Professional Ethical Crises : A Case Study of Accounting Majors. Managerial Auditing Journal, 21 (6), $636-656$.

Cooper, D. R., \& Schindler, P. S. (2006). Metode Riset Bisnis (9 ed., Vol. 2). (Budijanto, \& D. Djunaedi, Trans.) Jakarta: Media Global Edukasi.

Damayanthi, P. D., \& Juliarsa, G. (2016). Pengaruh Idealisme, Relativisme, Pengetahuan, Gender dan Umur pada
Perilaku Tidak Etis Akuntan. E-Jurnal Akuntansi Universitas Udayana, 15, 1-16.

Desmita. (2005). Psikologi Perkembangan. Bandung: PT Remaja Rosdakarya.

Dean, Kathy L., Jeri M. Beggs, and Charles J. Fornaciari. (2007). Teaching Ethics and Accreditation: Faculty Competence, Methods and Assessment. Journal of Business Ethics Education (NeilsonJournals) 4: 5-26.

Duska, R. F. (1991). What's the Point of a Business Ethics Course?. Business Ethics Quarterly, 1(4), 335-354.

Farhan, D. (2009). Etika dan Akuntabilitas Profesi Akuntan Publik. Malang: Intimedia.

Fauzan. (2013). Pengaruh Religiusitas terhadap Etika Berisnis. Jurnal Manajemen dan Kewirausahaan, 15(1), 53-64. doi:DOI: 10.9744/jmk.15.1.53-64

Galbraith, S. \&. (1993). Decision rules used by male and female business students in making ethical judgments. Journal of Business Ethics, 12, 227-233.

Ghozali, I. (2011). Aplikasi Analisisi Multivariate dengan Program IBM SPSS 19 (Edisi 5.). Semarang: Badan Penerbit Universitas Diponegoro.

Hair Jr., Yoseph F., Rolph E. Anderson, Ronald L. (2010). Multivariate Data Analysis. 7. Boston: Pearson.

Hartono, J. (2013). Metodologi Penelitian Bisnis. Yogyakarta: BPFE.

Kerr, David S \& Smith, L Murphy. (1995). Importance of and approaches to incorporating ethics into the accounting classroom. Journal of Business Ethics 14 (12): 987.

Kidwell, J. M., Stevens, R. E., \& Bethke, A. L. (1987). Differences in Ethical Perceptions Between Male and Female Managers: Myth or Reality?. Journal of Business Ethics, 6(6), 489. 
Kuncoro, M. (2003). Metode Riset untuk Bisnis dan Ekonomi. (Edisi 3). Jakarta: Erlangga.

Ludigdo, U. (1998). Persepsi Akuntan dan Mahasiswa terhadap Etika Bisnis. Thesis. Yogyakarta: ETD UGM.

Luthans, F. (2006). Perilaku Organisasi (Edisi 10). (v. A. Yuwono, S. Purwanti, T. A. P, \& W. Rosari, Trans.) Yogyakarta: ANDI.

Magill, G. (1992). Theology in Business Ethics: Appealing to the Religious Imagination. Journal of Business Ethics, 11, 129-135.

Matlin, M. W. (1998). Cognition. Ganaseo, New York: Harcourt Brace College Publisher.

Moberg, Dennis and Edward, Romar. (2003). Worldcom. Diakses dari https://www.scu.edu/ ethics/focusareas/businessethics/resources/worldcom/. 15 September 2016.

Oclock, P., \& Oklesehan, M. (1993). A Comparison of Ethical Perception of Business and Engineering Major. Journal of Business Ethics, 12(9), 677.

Okleshen, M., \& Hoyt, R. (1996). A cross cultural comparison of ethical perspectives and decision approaches of business students: United States of America versus New Zealand. Journal of Business Ethics, 15(5), 537.

Palmer, G. a. (1997). Gender in Management: A Sociological Perspective. The international Journal of Accounting and Busness Society, 5(1), 67-99.

Pascarella, E. T. (2005). How college affects students. A third decade of research.

Putri, L. K. (2015). Pengaruh Pendidikan Etika, Religiosity, Performa Akademik, Terhadap Tingkat Penelaran Moral Pada Pengambilan Keputusan Akuntansi. Laporan Penelitian. Yogyakarta: ETD UGM.
Robbins, S. P., \& Judge, T. A. (2008). Organization Behavior: Perilaku Organisasi. Jakarta: Salemba Empat.

Roxas, M. a. (2004). The Importance of Gender across Cultures in Ethical Decision Making. Journal of Business Ethics, 50(2), 149-165.

Sekaran, Uma. (2006). Research Methods For Business: Metodologii Penelitian untuk Bisnis. (Edisi 4). Jakarta: Salemba Empat.

Siagian, S. P. (1996. ). Etika bisnis. Jakarta: PT Pustaka Binaan Pressindo.

Smith, B. (2009). Ethical Ideology And Cultural Orientation: Understanding The Individualized Ethical Inclinations of Marketing Students. American Journal of Business Education. Vol. 2, No. 8, hal 2736.

Sudibyo, Bambang dkk. (1995). Kemiskinan dan Kesenjangan di Indonesia. Yogyakarta: Bagian Penerbitan Aditya Media.

Suliyanto. (2006). Metode Riset Bisnis. Yogyakarta: ANDI.

Suwardi, E., Artiningsih, A., \& Novmawan, M. R. (2014). Student Percepti on Business Ethics. Journal of Indonesian Economy and Business, 29, $251-258$.

Tim Penyususn Kamus Pusat Pembinaan dan Pengembangan Bahasa. (1995). Kamus Besar Bahasa Indonesia (Edisi 2). Jakarta: Balai Pustaka.

Trail, C. e. (2006). Impact of Field of Study, College and Year on Calculation of Cumulative Grade Point Average. Advances in Health Sciences Education, 13, 253-261.

Weibe, K. F. (1980). Personality Correlates of Intrinsic, Extrinsic and Non-Religious Orientations. Journal of Psychology, 105, 181-187.

Woodbine, G. P. (2009). Does Religiosity Influence Ethical Sensitivity? An 
Investigation on Malaysia Future Accountants. Malaysian Accounting Review, 8, 17-41.

Zhang, P. A. (2011). From High School to Collage: The Trantition of Black and
White Study. Journal of Black Studies, 42(5), 828-845. 